\title{
Review
}

\section{Applications of luminous bacteria enzymes in toxicology}

\author{
Valentina A. Kratasyuk ${ }^{1,2}$, Elena N. Esimbekova ${ }^{2,1}$
}

${ }^{1}$ Siberian Federal University, Svobodnii ave., 79, Krasnoyarsk 660041, Russia

${ }^{2}$ Photobiology Laboratory, Institute of Biophysics, Russian Academy of Sciences, Siberian Branch, Krasnoyarsk, 660036, Russia

Address correspondence to: Dr. E.N. Esimbekova, Institute of Biophysics SB RAS, Akademgorodok 50/50, Krasnoyarsk, 660036, Russia

E-mail: esimbekova@yandex.ru

Keywords: bioluminescence; luciferase; bioluminescent toxicity enzymatic assay; total toxicity; immobilization of enzymes 


\begin{abstract}
This review describes the principle and applications of bioluminescent enzymatic toxicity bioassays. This type of assays uses bacterial coupled enzyme systems: NADH:FMNoxidoreductase and luciferase to replace living organisms in developing cost-competitive biosensors for environmental, medical and industrial applications. These biosensors instantly signal chemical and biological hazards and allow for detecting a great amount of toxic compounds with advantages associated with fast results, high sensitivity, simplicity, low cost and safety of the procedure.
\end{abstract}




\section{Introduction}

Historically, the application of bacterial luminescence in toxicology began with the usage of luminous bacteria for ecological monitoring and they are still widely used [1-3]. These methods made it possible to determine environmental pollution by comparing the light emission intensity of luminous bacteria in control with samples. As opposed to other test objects such as paramecia, algae, crustaceans, and so on, the bioluminescent assay is faster (typically $<30 \mathrm{~min}$ ). However, as with other living organisms, living luminous bacteria is petulant. The failure to maintain the stable state of bacterial culture during measurements and storage results in low accuracy of measurement, a clear disadvantage of this method caused by the "petulance". The bacteria react to the appearance of toxic substances either by decreasing or by increasing the luminous intensity, often leading to ambiguous interpretation of results. Because of these shortcomings the assay based on luminous bacteria didn't show very good results in ecological laboratories. To overcome those difficulties it was suggested to use enzymes of luminous bacteria NAD(P)H:FMN-oxidoreductase and luciferase in soluble and immobilized forms [4, 5]. Since 1990, bioluminescent enzymatic toxicity assay has been developed [5], and is nowadays actively used in ecology, medicine, agriculture, and other areas [6-8].

\section{Principle of bioluminescent enzymatic toxicity assays}

The bacterial coupled enzyme system: NAD(P)H:FMN-oxidoreductase + luciferase $($ Red + Luc) involves two reactions:

$$
\begin{array}{cc}
\text { Luciferase }(\text { Luc }) \\
\mathrm{FMN} \cdot \mathrm{H}_{2}+\mathrm{RCHO}+\mathrm{O}_{2} \rightarrow \mathrm{FMN}+\mathrm{RCOOH}+\mathrm{H}_{2} \mathrm{O}+\mathrm{h} v, \\
N A D(P) H: F M N \text {-oxidoreductase }(\text { Red }) \\
\mathrm{NAD}(\mathrm{P}) \mathrm{H}+\mathrm{FMN}+\mathrm{H}^{+} \rightarrow \mathrm{NAD}(\mathrm{P})^{+}+\mathrm{FMN} \cdot \mathrm{H}_{2}
\end{array}
$$

In Reaction 1 the oxidation of long-chain aliphatic aldehydes (RCHO) involving reduced flavin mononucleotide is catalyzed by luciferase (Luc). One of the products of this reaction is a quantum of light (hv) in the blue-green spectrum. To provide luciferase with reduced flavin mononucleotide, the luciferase reaction is coupled with the reaction catalyzed by NAD(P)H:FMN-oxidoreductase (Red) (Reaction 2) [9].

Application of bioluminescent enzymatic toxicity assays is justified by the fact that Red as a part of these enzymatic assays is present in all living organisms, leading to good correlation between the effect of toxic substances on living organisms and that of the coupled enzyme 
system from the luminous bacteria [6]. The bioluminescent toxicity enzymatic assay is based on the inhibition of Red and/or Luc activities by the toxic components of analyzed samples [10-12].

A classification of inhibitors according to the mechanism of their influence on enzymes activity was proposed [13-14]. There are four possible ways in which exogenous compounds act on a bioluminescence: 1) influence on energy transport processes, 2) influence on hydrogen transport processes, 3) influence on electron transfer processes in bioluminescent enzymatic reactions, and 4) interaction of pollutants with the enzymes Red and Luc. Knowing the mechanisms, it is possible to predict the results and change the sensitivity of assays to certain pollutant groups [11-12, 15].

The bioluminescent enzymatic toxicity assay can be carried out using different schemes (Fig. 1). The first scheme places a cuvette with all the necessary components of the bacterial coupled enzyme system (enzymes, their substrates and buffer solution) into a bioluminometer, register the maximum steady light emission intensity $I_{c}$ (control), then add the sample or pollutant solution into the cuvette, and again registers the maximum light emission intensity $I_{\text {exp }}$ (Fig. 1A). This approach is the quickest and has demonstrated good repeatability of results.

\section{Fig. (1).}

When analyzing toxicity of the water samples, the toxicity coefficient $(T C)$ or luciferase index $(L I)$ are calculated according to the formulas [6]:

$$
\begin{gathered}
T C=\left[\left(I_{c}-I_{\text {exp }}\right) / I_{c}\right] \cdot 100 \% . \\
L I=\left(I_{\text {exp }} / I_{c}\right) \cdot 100 \% . \\
T C=100-L I .
\end{gathered}
$$

$T C$ and $L I$ are the degree of inhibition of the bacterial coupled enzyme system Red + Luc and the residual luminescence and in the presence of analyzed sample, respectively. The criterion of toxicity is a $50 \%$ decrease in the maximum of light emission for the bacterial coupled enzyme system Red + Luc after the analyzed sample is added, as compared to the control [6]. To estimate toxicity of individual substance values of $\mathrm{EC}_{50}$ and $\mathrm{EC}_{20}$ are calculated. They showed $50 \%$ and $20 \%$ of the loss of light intensity for the enzyme system Red + Luc. The decay constant $k_{d}$ is also estimated according to the following formula: $k_{\mathrm{d}}=\left[\ln \left(I_{2} / I_{1}\right)\right] / \Delta t$, where $I_{1}$ is the peak of light emission intensity, $I_{2}$ is the light emission intensity at the certain time after reaching the bioluminescence maximum, and $\Delta t$ is the time needed for $I_{1}$ to reach $I_{2}$ [16].

The second scheme involves testing of the control sample (usually distilled water or buffer solution) and analyzed sample in different cuvettes [17-18]. This approach is possible to achieve 
higher sensitivity of the assays to the toxic substances. The results are also calculated by the values of $T C$ and $k_{d}$. But in that case, it is possible to use one more parameter - the time when the coupled enzyme system reached the luminescence maximum ( $T_{\max } ;$ Fig. 1B) [16].

The principles of bioluminescent enzymatic toxicity assay were successfully used for the analysis of aquatic environments [19-21] as well as air and soil pollutions [22-23].

A new trend in using bioluminescent enzymatic toxicity assay is the assessment of detoxification of pollutant solutions by water-soluble humic substances (HSs). This method is based on the quantitative determination of the antioxidant activity of HSs. There were a few studies that promote application of the assay to monitor toxicity of pollutants of oxidative nature in environmental and waste waters during remediation procedures [24-27]. The bioluminescent enzymatic toxicity assays were applied to monitor changes in the toxicity of homologous quinones with different redox characteristics under exposure to HSs [28]. Toxicities of general and oxidative types were evaluated using bioluminescent kinetic parameters - bioluminescence intensity and $T_{\max }$, respectively. Antioxidant activity of HSs was attributed to their ability to decrease both general and oxidative toxicities. The HSs antioxidant efficiency was characterized with detoxification coefficients $\mathrm{D}_{\mathrm{GT}}$ and $\mathrm{D}_{\mathrm{OxT}}$, respectively. Dependency of $\mathrm{D}_{\mathrm{GT}}$ and $\mathrm{D}_{\mathrm{OxT}}$ on HSs concentration and time of preliminary incubation of the oxidizers with HSs were demonstrated. The optimal conditions for detoxification of the oxidizers were $>20$-min incubation time and from $50 \mu \mathrm{M}$ to $0.2 \mathrm{mM}$ of HSs concentration [24-27].

Bioluminescent enzymatic toxicity assay provides an instrument to solve a problem of complex evaluation of environmental toxicity. It is well-known that to estimate environmental toxicity it is necessary to use the battery of bioassays. Usually they represent different levels of organisms such us cells, organs, organisms and ecosystems. Due to the coupling with bacterial luciferase, it is possible to design new enzymatic assays in toxicology and combine them into a set to provide the toxicity control at the enzymatic level [29]. The set includes enzymes of different classes, or key enzymes of metabolic processes in living organisms. The bacterial luciferase may be the terminal enzyme in coupling chains for more than 100 enzymes including such as lactate dehydrogenase, trypsin, glucose-6-phosphate dehydrogenase, and others, making it possible to measure the enzyme activities according to the light emission intensity.

To develop the set of bioluminescent enzymatic toxicity assays different enzyme interaction mechanisms were suggested (Fig. 2). For example, in research by Kratasyuk et al. [19] to estimate toxicity of water samples two enzymes were chosen: alcohol dehydrogenase $(\mathrm{ADH})$ and trypsin, because they belong to different classes (oxidoreductases and hydrolases), and secondly, because they interact differently with bacterial luciferase, providing different 
sensitivity to the toxic substances [30-31]. The Influence of toxic compounds on the activities of the triple enzyme system with ADH and trypsin were measured using the bioluminescence decay constant (Fig. 3).

Fig. (2).

Fig. (3).

\section{Immobilised reagents for bioluminescent enzymatic toxicity assays}

Widespread use of the existing bioluminescent enzymatic toxicity assays is limited by the instability of the enzymes, limited shelf-life of enzymes-reagents, the need to control $\mathrm{pH}$, temperature and other ambient conditions, high manufacturing cost, and other factors. These problems can be solved by using immobilized enzymes that possess high catalytic activity and stability for long-term storage and successfully serve as biological modules of biosensors [34].

For the last 30 years immobilization has been widely used for production of stable reagents for bioluminescent analysis based on various bioluminescent systems: luminous bacteria, and bacterial and firefly luciferases. Many of the available immobilized reagents are successfully used in analytic measurements and in biosensors, because they simplify the analysis procedure, sometimes enabling full automation. At present, there are more than 40 different methods of immobilizing luminous organisms and enzymes [35]. An important advantage of immobilized enzymes is the possibility to control the enzyme stability to physical and chemical factors by way of choosing a suitable microenvironment [36]. The optimal environment for bacterial luciferase is natural polymer gels such as gelatin or starches (potato, rice, or corn). By varying gel concentration, time, and mode of drying of immobilized enzymes it is possible to make reagents with different enzymatic activity [37-40].

It was shown that coupled enzyme system Red + Luc immobilized in starch or gelatin gel, maintains its activity for 2 years [41-42]. Moreover, immobilization in these gels leads to a considerable stabilization of the coupled enzyme system with regard to denaturation treatment: $\mathrm{pH}$ optimum of the enzymes expands both to the acid and alkaline areas; high enzyme activity is maintained at increased salt concentration; thermal stability increases essentially, especially in case of starch gel immobilization [38, 43-44].

Several substrates of bacterial bioluminescent reaction can be co-immobilized together with the coupled enzyme system to make the final reaction mixture much simpler. For example, 
homogeneous multicomponent reagent named Enzymolum contains the enzymes Red and Luc, their substrates (myristic aldehyde and NADH) and buffer salts, co-immobilized in gelatin or starch gel [40]. The reagent can be used in the cuvette bioluminometer since it is currently produced in tablet form (Fig. 4).

Fig. (4).

The rapidity (the time of analysis does not exceed $5 \mathrm{~min}$ ), a one-step measuring procedure, high sensitivity and the possibility of automation are the advantages of enzymatic assays using Enzymolum [6, 18].

\section{Bioluminescent enzymatic toxicity assays of individual toxic substances}

Assay of acrylonitrile in air was one of the first cases when bioluminescent enzymatic toxicity assay was applied for air toxicity control. Acrylonitrile is a carcinogenic compound and may be the reason of lung cancer. Therefore, it is very important to control the acrylonitrile content in air at the facilities of chemical industry. To prepare the sample for the assay acrilonitrile was accumulated from air by bubbling through the ethanol where acrylonitrile split into cyanide products which inhibit luciferase activity. The lower level of acrylonitrile detection was 10 $\mathrm{mg} \cdot \mathrm{L}^{-1}[45]$. This example also shows that when the substance itself does not affect the intensity of light emission, it is still possible to build the analysis based on its decaying products.

2,4-dinitrofluorobenzene (DNFB) is used for peptides assays. It can cause allergy and has mutagenic effect, LD $50>100 \mathrm{mg} \cdot \mathrm{kg}^{-1}$. DNFB changes the parameters of the coupled enzyme system Red + Luc by decreasing the maximum of luminescence intensity and increasing the time of the luminescence maximum reaching. DNFB didn't inhibit the reaction catalyzed by Red, but decreased light emission due to competitive inhibition of $\mathrm{FMNH}_{2}$-binding center of luciferase. The sensitivity of the assay to DNFB was up to $0.5 \mu \mathrm{M}$ [46-47].

In study [48] the sorption effect of platinum compounds on human skin has been demonstrated and the bioluminescent enzymatic toxicity assay was proposed to control skin purity polluted by platinum hydrochloride acid (PHCA). Authors proposed to use this assay to prevent allergic disease as being toxic, platinum metal compounds can cause a number of allergic diseases called platinosis. Wide industrial application of these compounds demands the development of the assay for platinoid identification on workers clothes and skin both for preventive purposes and for determination of metal loss [48-49]. 
Succinic acid sulfoderivatives are a promising group of compounds with diverse pharmacological activity. Biological effects of the compounds with two different in structure groups including N-(arylsulfonamido) succinimides and hydroxyamides of arensulfohydrosides of succinic acid on in vivo (based on luminous bacteria) and in vitro (based on Red and Luc) bioluminescence were estimated [15]. The influence of compounds on luminous bacteria varies from increasing light intensity or the lack of effect at all to inhibition action. The authors concluded that the increase in light intensity was observed for high lipophilic compounds while the inhibitory effect was estimated for hydrophilic ones. On the contrary the effect of the compounds on luciferase activity has been shown practically not to depend on their lipophilic characteristics. Most of these substances inhibited the luciferase reaction when their concentrations were in range of $10 \mathrm{nM}$ to $1 \mu \mathrm{M}$.

At present due to increasing scale of production and huge amount of nanomaterials used in industrial and economic activity, a new field of toxicological assay named nanotoxicology has appeared [50-51]. Bioluminescent methods based on the use of recombinant or natural strains of luminous bacteria showed good results in terms of rapidity [52-56], but some authors pointed that it is more important to evaluate the molecular mechanism of nanomaterials effect [57-59]. The bioluminescent enzymatic toxicity assay based on soluble or immobilized coupled enzyme system Red + Luc was used to estimate the toxicity of carbon nanomaterials represented by single- and multi-walled nanotubes (SWCNTs and MWCNTs) and by aqueous solutions of hydrated fullerene $\mathrm{C}_{60}\left(\mathrm{C}_{60} \mathrm{HyFn}\right)$. The majority of the investigated nanomaterials were characterized by an inhibitory effect on the coupled enzyme system. It was found that the soluble coupled enzyme system is more sensitive to the toxic effect of MWCNTs and SWCNTs, while immobilized one to the effect of $\mathrm{C}_{60} \mathrm{HyFn}$. The carbon nanomaterials toxicity decreased in the series MWCNTs > SWCNTs > $\mathrm{C}_{60} \mathrm{HyFn}$, which was correlated with the results of other biological methods.

The principles of bioluminescent enzymatic toxicity assays were applied to analyze not only the pollutants toxicity, but to estimate the safety of the new engineered substances, for example polyhydroxyalkanoates (PHAs). Currently PHAs are widely used in surgery, orthopedics cardio- and vascular surgery, tissue engineering as well as in food industry as packing and fillers [61-66]. PHAs - polyesters of fatty acids oxyderivatives are classified as the natural polymers. They are characterised by plasticity, optical and antioxidant activity, piezoelectric properties, biodegradability and biocompatibility. In research by Shishatskaya et al. [67] the toxicity evaluation of experimental PHAs samples synthesized by bacteria Alcaligenes eutrophus B5786 was performed. The tested samples consisted of homogeneous polymer of 
polyhydroxybutyrate beta-hydroxybutyric acid and bicomponent copolymers of betahydroxybutyrate and beta-oxyvaleriate. Studied were aqueous extracts of PHAs polymer film in the ratio of square to volume $(1 \mathrm{~cm}: 1 \mathrm{ml})$. The extracts prepared at $37^{\circ} \mathrm{C}$ in dynamic mode: after 3 days first extracts were collected and new portion of water was poured to PHAs and collected again after 7 days; new portion of distilled water poured again for 10 days. Distilled water heated in the same way was the control sample. The reaction of all enzyme systems included to the set of the bioluminescent enzymatic toxicity assays showed no dependency upon time of PHAs exposure to water proved the low biological activity of studied PHAs samples. The results were supported by in vivo experiments on white mice [67].

\section{Bioluminescent enzymatic toxicity assays in agriculture and food industry}

Bioluminescent enzymatic toxicity assays are used not only in ecology but also in other sectors, such as agriculture and food industry. Mostly method of assessing bacterial contamination, based on firefly ATP-dependent luciferase is applied [66-67]. However similar methods for detecting living bacterial cells were developed using luminous bacteria enzymes Red + Luc [70-71]. The bioluminescent assay of L-and D-lactate in beer has been designed [72]. Nevertheless methods based on the use of enzymatic bioluminescent bacterial system Red + Luc are applied for food product quality rarely. Examples of bioluminescent enzymatic toxicity assays for agriculture and food industry are presented below.

The first example is evaluation of wheat grain infection with Fusarium. Mycotoxins of fungi of the genus Fusarium in feeding causes poisoning and even death of animals. International standards for grain quality and medical and biological requirements for food quality require that grain contamination with Fusarium should be controlled at the stages of crop harvesting, purchase, and processing. To develop rapid analysis of wheat grain infection with Fusarium the effects of their mycotoxins on the coupled enzyme system were studied at first and the strong inhibition of enzymatic activity was observed. The sensitivity of the coupled enzyme system Red + Luc to mycotoxins decreased in the following order: zearalenone, deoxynivalenol, toxin T-2, and diacetoxiscripenol [73]. Further, in study [74] it has been shown that the efficiency of Red + Luc activity inhibition by wheat extracts depended on the severity of grain infection with Fusarium. Moreover, the inhibition was caused not only by mycotoxins but also by other metabolites of Fusarium, which were accumulated in infected grain. The inhibition of bioluminescence depended on the geographical origin and growth conditions of the grain. These differences were able to minimize due to the method of sample preparation [74]. 
Another example is assessment of food additives safety. The sodium benzoate (E 211), potassium sorbate (E 202) and sorbic acid (E 200) and such nanomaterials as $\mathrm{Ag}, \mathrm{Cu}, \mathrm{Cu}_{2} \mathrm{O}$ were tested [75]. The loss of luminescence intensity of the coupled system Red + Luc in the presence of food additives was estimated. The toxic effects of additives on the bioluminescence of the three triple enzyme systems Red + Luc + trypsin, Red + Luc + ADH and Red + Luc + LDH (lactate dehydrogenase) were analyzed [75].

The results of the well-known bioassays based on germinating of shoots and roots of cress "Cudriavyy", survival and chemotaxis ciliates Paramecium caudatum, changes in the level of chlorophyll fluorescence of algae Scenedesmus spp., survival of Daphnia magna, and foaming by the yeast Saccharomyces cerevisiae were compared to the results of bioluminescent bioassays. The parameters $\mathrm{EC}_{50}$ or $\mathrm{LD}_{50}$ were calculated to evaluate the effects of the food additives on organisms [75].

The coupled enzyme system Red + Luc and triple enzyme system with LDH were the most sensitive to the analyzed preservatives. Values of $\mathrm{EC}_{50}$ for sodium benzoate, potassium sorbate and sorbic acid were equal 0.03, 0.14, 0.008 and 0.66, 0.13, $0.07 \mathrm{mM}$ for Red + Luc and Red + Luc $+\mathrm{LDH}$, respectively. The values of $\mathrm{EC}_{50}$ estimated by enzymatic assays were over two times less than that for the biological assays mentioned above [75]. It was shown that both copper and copper oxide (I) nanoparticles had a strong inhibitory effect on Red + Luc. Values of $\mathrm{EC}_{50}$ were equal $4 \mu \mathrm{M}$ and $1.5 \mu \mathrm{M}$ for copper nanoparticles and $\mathrm{Cu}_{2} \mathrm{O}$, respectively. Value of $\mathrm{EC}_{50}$ for silver nanoparticles was $0.18 \mathrm{mM}$ [75]. The bioluminescent enzymatic toxicity assay indicated the negative effect of food additives in the much lower concentrations than its actual maximum content in food products.

There is a problem which is extremely vital both for agriculture and food industry. It is pesticides. Pesticides can be carcinogenic or mutagenic, or they can affect the endocrine, respiratory, immune or nervous systems [76-77]. There are two different types of pesticides: organophosphates and pyrethroids. Organophosphorous substances are complex esters of phosphoric acid and their toxic effect is accounted for by their ability to inhibit acetyl cholinesterase, the key enzyme in synaptic transmission in nerves [76, 78]. Pyrethroid insecticides, synthetic analogues of natural pyrethrins, act through intestinal contact, thereby affecting the nervous and the immune systems [79-80]. In study by Vetrova et al. [16] the set of bioluminescent enzymatic toxicity assays was applied to analyze toxicity of organophosphorous and pyrethroid pesticides. The sensitivities of the bioluminescence assays were close to those determined by other biological assays or even higher [16]. The sensitivity of triple enzyme systems with $\mathrm{ADH}$ and trypsin to organophosphorous compounds were $0.13-11 \mathrm{mg} \cdot \mathrm{L}^{-1}$. 
Sensitivities of the triple enzyme systems to pyrethroid pesticides were similar to those of in vivo assay based on luminous bacteria $\left(0.9-5 \mathrm{mg} \cdot \mathrm{L}^{-1}\right)$.

\section{Bioluminescent enzymatic toxicity assays in medicine}

Bioluminescent enzymatic toxicity assays are also very promising for use in medical research, for example for evaluating the gravity of endotoxicosis during treatment in surgery and therapy. This is based on the fact that the effect of the blood serum of donors on this assay differs markedly from that of patients. It has been shown that blood serum of a patient inhibits bioluminescence less than that of a donor. Two modifications of the assay using luciferase and coupled enzyme system Red + Luc have been developed.

Comparative analysis of the usefulness of the luciferase index $(L I)$ and other laboratory parameters to assess patients with peritonitis have also been made [81]. Bioluminescent assays allow estimation of a patient's condition as satisfactory, of mildly serious, severe, or critical [8182]. The assays can be used also for prediction of the course of the disease, estimation of the efficiencies of the used detoxification methods and of the drainage procedure with semipermeable membranes [83]. Most important is applying $L I$ in a prognostic plan in so far as the long low-positive $L I$ dynamics could indicate the need for a change of treatment plan.

It was reported that bioluminescent enzymatic toxicity assay can be used as a reliable criterion to monitor the course of disease for patients undergoing therapy for bronchitis, peptic ulcer, and chronic cholecystitis [84]. The very short time interval between sample collection and results, high sensitivity, low traumatism, and simplicity are the most important advantages of the proposed assay [84].

A very interesting and promising trend in the development of bioluminescent enzymatic toxicity assay is the creation of rapid analysis for the assessment of human organism reaction to physical and mental stress. Analysis is made by comparing the light emission intensity of the coupled enzyme system Red + Luc in the presence of a person's saliva taken before and after a certain stress load. The main advantage of the assay is noninvasiveness, because human saliva is analyzed, which reflects the functional state of a person just as blood does [85].

\section{CONCLUSION}

In summary, we describe here a new approach in developing bacterial bioluminescent enzymatic biosensors, application to toxicity bioassays, and the needed reagents. To solve the problem of how to detect, identify, and measure the numerous chemical compounds in environmental 
monitoring, food product contamination, and medical diagnostics, the bioluminescent enzymatic toxicity assays were proposed, wherein the bacterial coupled enzyme system NAD(P)H:FMNoxidoreductase-luciferase substitutes for older methods using living organisms. The immobilized reagent Enzymolum was used to facilitate and accelerate the development of the bioluminescent enzymatic systems as biological part of biosensors for toxicological assays. The reagent is easy to use and convenient to be applied not only in toxicology studies but also in education, mainly in ecological and enzymological practical courses [86-88]. Prototype biosensors offer cost advantages, versatility, high sensitivity, rapid response, extended shelf-life and flexible storage conditions.

\section{ACKNOWLEDGEMENTS}

The research was supported by the Russian Science Foundation, project № №15-19-10041.

\section{REFERENCES}

- [1] Girotti, S.; Ferri, E.N.; Fumo, M.G.; Maiolini, E. Monitoring of environmental pollutants by bioluminescent bacteria. Anal. Chim. Acta, 2008, 608, 2-29.

- [2] Fernández-Piñas, F.; Rodea-Palomares, I.; Leganés, F.; González-Pleiter, M.; Angeles Muñoz-Martín, M. Evaluation of the ecotoxicity of pollutants with bioluminescent microorganisms. Adv. Biochem. Eng. Biotechnol., 2014, 145, 65-135.

- [3] Xu, T.; Close, D.; Smartt, A.; Ripp, S.; Sayler, G. Detection of organic compounds with whole-cell bioluminescent bioassays. Adv. Biochem. Eng. Biotechnol., 2014, 144, 111-151.

- [4] Jung, I.; Seo, H.B.; Lee, J.E.; Kim, B.C.; Gu M.B. A dip-stick type biosensor using bioluminescent bacteria encapsulated in color-coded alginate microbeads for detection of water toxicity. Analyst, 2014, 139, 4696-701.

- [5] Kratasyuk, V.A. Principle of luciferase biotesting. In: Proceeding of the first international school "Biological luminescence", Wroclaw, Poland, 20-23 June 1989. World Scientific Publishing Co.: Singapore, 1990; pp. 550-558.

- [6] Esimbekova, E.; Kratasyuk, V.; Shimomura, O. Application of enzyme bioluminescence in ecology. Adv. Biochem. Eng. Biotechnol., 2014, 144, 67-109.

- [7] Roda, A.; Guardigli, M.; Michelini, E.; Mirasoli, M. Bioluminescence in analytical chemistry and in vivo imaging. Trends in Anal. Chem., 2009, 28, 307-322. 
- [8] Kratasyuk, V.A.; Kuznetsov, A.M.; Rodicheva, E.K.; Egorova, O.I.; Abakumova, V.V.; Gribovskaya, I.V.; Kalacheva, G.S. Problems and prospects of bioluminescence assays in ecological monitoring. Sib. J Ecol., 1996, 5, 397-403.

- [9] Shimomura, O. Bioluminescence: chemical principles and methods. Rev. ed. World Scientific Publishing Co. Pte. Ltd, Singapore, 2006.

- $\quad$ [10] Kudryasheva, N.S.; Kratasyuk, V.A.; Esimbekova, E.N.; Vetrova, E.V.; Nemtseva, E.N.; Kudinova, I.Y. Development of the bioluminescent bioindicators for analyses of environmental pollutions. Field Anal. Chem. Tech., 1998, 2, 277-280.

- [11] Kudryasheva, N.; Vetrova, E.; Kuznetsov, A.; Kratasyuk, V.; Stom, D. Bioluminescent assays: effects of quinones and phenols. Ecotox. Environ. Safe., 2002, 53, 221225.

- [12] Vetrova, E.V.; Kudryasheva, N.S.; Kratasyuk, V.A. Redox compounds influence on the NAD(P)H:FMN-oxidoreductase-luciferase bioluminescent system. Photoch. Photobiol. Sci., 2007, 6, 35-40.

- [13] Kudryasheva, N.S. Bioluminescence and exogenous compounds. Physico-chemical basis for bioluminescent assay. J Photochem. Photobiol. B, 2006, 83, 77-86.

- [14] Kudryasheva, N.S. Nonspecific effects of exogenous compounds on bacterial bioluminescent enzymes: fluorescence study. Curr. Enzym. Inhib., 2006, 2, 363-372.

- [15] Kratasyuk, V.A.; Makurina, V.I.; Kuznetsov, A.M.; Kudryashova, N.S.; Plotnikova, N.B.; Mededeva, S.E.; Gritsenko, I.S.; Chernykh, V.P. Study of effect of sulfo-substituted succinic acid on bacterial luminescence. Appl. Biochem. Micro. (Moscow), 1991, 27, 127-133.

- [16] Vetrova, E.; Esimbekova, E.; Remmel, N.; Kotova, S.; Beloskov, N.; Kratasyuk, V.; Gitelson, I. A bioluminescent signal system: detection of chemical toxicants in water. Luminescence, 2007, 22, 206-214.

- [17] Kratasyuk, V.A.; Esimbekova, E.N. Express method for biotesting of natural, manufacturing waters and water solutions. Patent RU 2,413,771, March 10, 2011.

- [18] Esimbekova, E.; Kondik, A.; Kratasyuk, V. Bioluminescent enzymatic rapid assay of water integral toxicity. Environ. Monit. Assess., 2013, 185, 5909-5916.

- [19] Kratasyuk, V.A.; Esimbekova, E.N.; Gladyshev, M.I.; Khromichek, E.B.; Kuznetsov, A.M.; Ivanova, E.A. The use of bioluminescent biotests for study of natural and laboratory aquatic ecosystems. Chemosphere, 2001, 42, 909-915.

- [20] Kratasyuk, V.A.; Vetrova, E.V.; Kudryasheva, N.S. Bioluminescent water quality monitoring of salt Lake Shira. Luminescence, 1999, 14, 193-195. 
- [21] Vetrova, E.V.; Kratasyuk, V.A.; Kudryasheva, N.S. Bioluminescent characteristics of Shira Lake water. Aquat. Ecol., 2002, 36, 309-315.

- [22] Rimatskaya, N.V.; Nemtseva, E.V.; Kratasyuk, V.A. Bioluminescent assays for monitoring of air pollution. Luminescence, 2012, 27, 154.

- [23] Rimatskaia, N.; Baigina, E.; Kazanceva, M.; Stom, D.; Kratasyuk V. Application of bioluminescent enzymatic method for assessment of the state of the soil. Luminescence, 2014, 29, 66-67.

- [24] Tarasova A.S.; Stom D.I.; Kudryasheva N.S. Effect of humic substances on toxicity of inorganic oxidizer. Bioluminescent monitoring. Environ. Toxicol. Chem., 2011, 30, 10131017.

- [25] Tarasova A.S.; Kislan S.L.; Fedorova E.S.; Kuznetsov A.M.; Mogilnaya O.A.; Stom D.I.; Kudryasheva N.S. Bioluminescence as a tool for studying detoxification processes in metal salt solutions involving humic substances. J Photoch. Photobio. B, 2012, 117, 164-170.

- [26] Tarasova A.S.; Stom D.I.; Kudryasheva N.S. Antioxidant activity of humic substances via bioluminescent monitoring in vitro. Environ. Monit. Assess., 2015, 187. 89.

- [27] Kudryasheva, N.S.; Tarasova, A.S. Pollutant toxicity and detoxification by humic substances: mechanisms and quantitative assessment via luminescent biomonitoring. Environ. Sci. Pollut. Res., 2015, 22, 155-167.

- [28] Fedorova, E.S.; Kudryasheva, N.S.; Kuznetsov, A.M.; Mogil'naya, O.A.; Stom, D.I. Bioluminescent monitoring of detoxication processes: activity of humic substances in quinone solutions. J Photochem. Photobiol. B, 2007, 88, 131-136.

- [29] Kratasyuk, V.A.; Gitelson, J.I. Application of luminous bacteria in bioluminescent analysis. Uspekhi microbiologii, 1987, 21, 3-30.

- [30] Kudryasheva, N.S.; Kudinova, I.Y.; Esimbekova, E.N.; Kratasyuk, V.A.; Stom, D.I. The influence of quinones and phenols on the triple $\mathrm{NAD}(\mathrm{H})$-dependent enzyme systems. Chemosphere, 1999, 38, 751-758.

- [31] Kudryasheva, N.S.; Esimbekova, E.N.; Remmel, N.N.; Kratasyuk, V.A. Effect of quinones and phenols on the triple enzyme bioluminescent system with protease. Luminescence, 2003, 18, 224-228.

- [32] Petushkov, V.; Shefer, L.; Rodionova, N.; Fish, A. Bioluminescent method of determination of NAD(P)H dehydrogenase activity. Appl. Biochem. Biotech., 1987, 23, 270-274.

- [33] Njus, D.; Baldwin, T.O.; Hastings, J.W. A sensitive assay for proteolytic enzymes using bacterial luciferase as a substrate. Anal. Biochem., 1974, 61, 280-287. 
- [34] Turner, A.P.F. Biosensors - sense and sensitivity. Science, 2000, 290, 1315-1317.

- [35] Kratasyuk, V.A.; Esimbekova, E.N. Polymer immobilized bioluminescent systems for biosensors and bioinvestigations. In: Polymeric biomaterials, The PBM Series (Introduction to Polymeric Biomaterials); Arshady R., Ed.; Citus Books: London, 2003; 1, pp. 301-343.

- [36] Esimbekova. E., Bezrukikh, A., Orlova, A., Kratasyuk, V. Enzyme-based bioluminescent biosensors: mechanisms of biological module stabilization. Luminescence, 2010, 25, 195-196.

- [37] Esimbekova, E.N.; Kratasyuk, V.A.; Torgashina, I.G. Disk-shaped immobilized multicomponent reagent for bioluminescent analyses: correlation between activity and composition. Enzyme Microb. Tech., 2007, 40, 343-346.

- [38] Esimbekova, E.N.; Torgashina, I.G.; Kratasyuk, V.A. Comparative study of immobilized and soluble NADH:FMN-oxidoreductase-luciferase coupled enzyme system. Biochemistry (Moscow), 2009, 74, 695-700.

- [39] Esimbekova, E.N.; Lonshakova-Mukina, V.I.; Bezrukikh, A.E.; Kratasyuk, V.A. Design of multicomponent reagents for enzymatic assays. Dokl. Biochem. Biophys., 2015, 461, 102-105.

- [40] Kratasyuk, V.A., Esimbekova, E.N. (2011) Bioluminescent biomodule for analyses of various media toxicity and method of its preparation. Patent RU 2,413,772, March 10, 2011.

- [41] Lonshakova, V.I.; Esimbekova, E.N.; Kratasyuk, V.A. Characteristics of coupled enzymatic system of luminous bacteria co-immobilized with substrates and stabilizers into starch gel. Luminescence, 2012, 27, 135-136.

- [42] Lonshakova-Mukina, V.; Esimbekova, E.; Kratasyuk, V. Impact of enzyme stabilizers on the characteristics of biomodules for bioluminescent biosensors. Sensor. Actuat. BChem., 2015, 213, 244-247.

- [43] Bezrukikh, A.E.; Esimbekova, E.N.; Kratasyuk, V.A. Gelatin and starch for bacterial luciferase stabilization. Luminescence, 2012, 27, 114-115.

- [44] Bezrukikh, A.; Esimbekova, E.; Nemtseva, E.; Kratasyuk, V.; Shimomura, O. Gelatin and starch as stabilizers for the coupled enzyme system of luminous bacteria NADH:FMN-oxidoreductase-luciferase. Anal. Bioanal. Chem., 2014, 406, 5743-5747.

- [45] Kratasyuk, V.A.; Kruchinina, R.I.; Kuznetsov, A.M.; Ivanov, V.V.; Fish, A.M. The method to determine concentration of acrylonitrile. Patent RU 1,270,658, July 15, 1986. 
- [46] Kratasyuk, V.A.; Fish, A.M. Study of the mechanism of the action of 2,4dinitrofluorobenzene on bacterial luminescence in vitro. Biochemistry-Moscow, 1980, 45, 895900.

- [47] Kratasyuk, V.A.; Kuznetsov, A.M.; Fish, A.M.; Gitelson, J.I. The method to determine concentration of the inhibitors of biological activity. Patent RU 865,904, September $23,1981$.

- [48] Oborina, R.I.; Kratasyuk, V.A. Biotests in detection of platinoid contamination of the skin. Meditsina Truda I Promyshlennaya Ekologiya, 1989, 12, 42-44.

- [49] Kratasyuk, V.A.; Kruchinina, R.I.; Kuznetsov, A.M.; Fish, A.M.; Makarenko, V.D. The method to determine concentration of the inhibitors of biological activity. Patent RU 1,204,639, September 5, 1985.

- [50] Sahu, S.C.; Casciano, D.A. Eds. Nanotoxicity: from in vivo and in vitro models to health risks. John Wiley \& Sons, Ltd. 2009.

- [51] Kewal, K.J. The Handbook of Nanomedicine. 2nd ed.; Humana Press, 2012.

- [52] Maurer-Jones, M.A.; Gunsolus, I.L.; Murphy, C.J.; Haynes, C.L. Toxicity of engineered nanoparticles in the environment. Anal. Chem., 2013, 85, 3036-3049.

- [53] Mortimer, M.; Kasemets, K.; Heinlaan, M.; Kurvet, I.; Kahru, A. High throughput kinetic Vibrio fischeri bioluminescence inhibition assay for study of toxic effects of nanoparticles. Toxicol. in vitro, 2008, 22, 1412-1417.

- [54] Zheng, H.; Liu, L.; Lu, Y.; Long, Y.; Wang, L.; Ho, K.P.; Wong, K.Y. Rapid determination of nanotoxicity using luminous bacteria. Anal. Sci., 2010, 26, 125-128.

- [55] Deryabin, D.G.; Aleshina, E.S.; Efremova, L.V. Application of the inhibition of bacterial bioluminescence test for assessment of toxicity of carbon-based nanomaterials. Microbiology, 2012, 81, 492-497.

- $\quad$ [56] Chey, C.O.; Patra, H.K.; Tengdelius, M.; Golabi, M.; Parlak, O.; Imani, R.; Elhag, S.A.I.; Yandi, W.; Tiwari A. Impact of nanotoxicology towards technologists to end users. Adv. Mat. Lett., 2013, 4, 591-597.

- [57] Käkinen, A.; Ding F.; Chen, P.; Mortimer, M.; Kahru, A.; Ke, P.C. Interaction of firefly luciferase and silver nanoparticles and its impact on enzyme activity. Nanotechnology, 2013, 24, 345101 .

- [58] Zhang, F.; Wang, N.; Chang, F.; Bi, S. Deriving TC 50 values of nanoparticles from electrochemical monitoring of lactate dehydrogenase activity indirectly. Methods Mol. Biol., 2012, 926, 113-130. 
- [59] Wang, Z.; Zhao, J.; Li, F.; Gao, D.; Xing, B. Adsorption and inhibition of acetylcholinesterase by different nanoparticles. Chemosphere, 2009, 77, 67-73.

- [60] Wang, Z.; Zhang, K.; Zhao, J.; Liu, X.; Xing, B. Adsorption and inhibition of butyrylcholinesterase by different engineered nanoparticles. Chemosphere, 2010, 79, 86-92.

- [61] Volova, T.G.; Shishatskaya, E.I.; Sinskey, A.J. Degradable Polymers: Production, Properties and Applications. Nova Sci. Publ., 2013.

- [62] Chen, G.Q.; Wu, Q. The application of polyhydroxyalkanoates as tissue engineering materials. Biomaterials, 2005, 26, 6565-6578.

- [63] Chanprateep, S. Current trends in biodegradable polyhydroxyalkanoates. J Biosci. Bioeng., 2010, 110, 621-632.

- [64] Shishatskaya, E.I.; Goreva, A.V.; Kalacheva. G.S.; Volova, T.G. Biocompatability and resorption of intravenously administered polymer microparticles in tissue of internalorgans of laboratory animals. J Biomater. Sci.-Polym. E., 2011, 22, 2185-2203.

- [65] Murueva, A.V.; Shishatskaya, E.I.; Kuzmina, A.M.; Volova, T.G.; Sinskey, A.J. Microparticles prepared from biodegradable polyhydroxyalkanoates as matrix for encapsulation of cytostatic drug. J Mater. Sci: Mater. Med., 2013, 24, 1905-1915.

- [66] Masood, F., Yasin, T., Hameed, A. Polyhydroxyalkanoates - what are the uses? Current challenges and perspectives. Crit. Rev. Biotechnol., 2014, 25, 1-8.

- [67] Shishatskaya, E.I.; Esimbekova, E.N.; Volova, T.G.; Kalacheva, G.S.; Kratasyuk, V.A. Hygienic assessment of polyhydroxyalkanoates - natural polyethers of new generation. Gigiena Sanitaria, 2002, 4, 59-63.

- [68] Frundzhyan, V.; Ugarova, N. Bioluminescent assay of total bacterial contamination of drinking water. Luminescence, 2007, 22, 241-244.

- [69] Lehto, M.; Kuisma, R.; Määttä, J.; Kymäläinen, H.-R.; Mäki, M. Hygienic level and surface contamination in fresh-cut vegetable production plants. Food Control, 2011, 22, 469475.

- [70] Mei, C.; Wang, J.; Lin, H.; Wang, J. Quantitative detection of NADH by in vitro bacterial luciferase bioluminescent. Wei Sheng Wu Хие Bao, 2009, 49, 1223-1228.

- [71] Peng, Y.; Jin, Y.; Lin, H.; Wang, J.; Khan, M.N. Application of the VPp1 bacteriophage combined with a coupled enzyme system in the rapid detection of Vibrio parahaemolyticus. J. Microbiol. Meth., 2014, 98, 99-104. 
- [72] Girotti, S.; Muratori, M.; Fini, F.; Ferri, E.N.; Carrea, G.; Koran, M.; Rauch, P. Luminescent enzymatic flow sensor for D- and L-lactate assay in beer. Eur. Food Res. Technol., 2000, 210, 216-221.

- $\quad$ [73] Kratasyuk, V.A.; L’vova, L.S.; Egorova, O.I.; Kudryasheva, N.S.; Orlova, N.Yu.; Bytev, V.O. Effect of Fusarium mycotoxins on a bacterial bioluminescence system in vitro. Appl. Biochem. Micro. (Moscow), 1998, 34, 190-192.

- [74] Kratasyuk, V.A.; Egorova, O.I.; Esimbekova, E.N.; Kudryashova, N.S.; Orlova, N.Yu.; L'vova, L.S. A biological luciferase test for the bioluminescent assay of wheat grain infection with Fusarium. Appl. Biochem. Micro. (Moscow), 1998, 34, 622-624.

- [75] Asanova, A.; Esimbekova, E.; Kratasyuk, V. Bioluminescent enzymatic methods for toxicological safety testing of food additives. Luminescence, 2014, 29, 74.

- [76] Galloway, T.; Handy, R. Immunotoxicity of organophosphorous pesticides. Ecotoxicology, 2003, 12, 345-363.

- [77] Hansen, O.Ch. Quantitative structure-activity relationships (QSAR) and pesticides. From Danish ministry of the environment: environmental protection agency. Pesticides Res., 2004, 94, 134. http://www2.mst.dk/udgiv/publications/2004/87-7614-434-8/pdf/87-7614-435$\underline{6 . p d f}$

- [78] Lundebye, A.K.; Curtis, T.M.; Braven, J.; Depledge, M.N. Effect of the organophosphorous pesticide, dimethoate, on cardic and acetylcholinesterase (AChE) activity in the shore crab Carcinus menaeus. Aquat. Toxicol., 1997, 40, 23-36.

- [79] Pauluhn, J., Machemer, L.H. Assessment of pyrethroid-induced paraesthesias: comparison of animal model and human data. Toxicol. Lett., 1998, 96-97, 361-368.

- $\quad$ [80] Diel, F.; Horr, B.; Borck, H.; Irman-Florjanc, T. Pyrethroid insecticides influence the signal transduction in $\mathrm{T}$ helper lymphocytes from atopic and nonatopic subjects. Inflamm. Res., 2003, 52, 154-163.

- [81] Voyevodina, T.V.; Nifantyev, O.Y.; Kovalevsky, A.N.; Shults, V.R.; Kratasyuk, V.A. Biofluorescence measurement of the body intoxication in peritonitis. Laboratornoe delo, 1990, 9, 23-25.

- [82] Sovtsov, S.A.; Kratasyuk, V.A. Determination of endotoxicosis under surgery. Patent RU 1,714,512, October 22, 1991.

- $\quad$ [83] Kratasyuk, V.A.; Kovalevskiy, A.N.; Voevodina, T.V.; Shulz, V.R.; Nifantiev, O.E. Determination of patients' state under endotoxicosis of infectious genesis. Patent RU 1,663,548, March 15, 1991. 
- [84] Esimbekova, E.N.; Kratasyuk, V.A.; Abakumova, V.V. Bioluminescent method nonspecific endotoxicosis in therapy. Luminescence, 1999, 14, 197-198.

- [85] Gritsenko, E.V.; Borodulin, S.V.; Bytev, V.O.; Kratasyuk, V.A. Bioluminescent control of sports training. In: Proceeding of the $7^{\text {th }}$ Russian symposium "Correction of homeostasis", Krasnoyarsk, Russia, 17-22 March 1996. pp. 232-233.

- [86] Gitelson, J.I.; Kratasyuk, V.A. Bioluminescence as an educational tool. In: Bioluminescence and chemiluminescence: progress and current applications; Kricka L.J., Stanley P.E. Eds. World scientific publishing: River Edge, 2002; pp. 175-182.

- [87] Kratasyuk, V.A.; Gusev, S.M.; Remmel, N.N. et al. Bioluminescence in the spaceflight and life science training program at Kennedy space center. In: Bioluminescence and chemiluminescence: chemistry, biology and applications; Szalay A., Hill P., Kricka L., Stanley P., Eds.; World scientific publishing: San Diego, 2007, pp. 257-260.

- [88] Kudryashev, M.A.; Gavrichkova, O.V.; Kudryasheva, N.S. Use of bacterial bioluminescent bioassay by schoolchildren for ecology monitoring and relations with human health. In: Bioluminescence and chemiluminescence: progress and current applications. Kricka L.J., Stanley P.E., Eds., World Scientific Publishing: River Edge, 2002, pp. 399-402. 


\section{Figure legends}

Fig. (1). (A) Bioluminescent assay scheme; (B) modified scheme of bioluminescent assay. $I$ is bioluminescence intensity in relative units; $I_{c}$ and $I_{\exp }$ are maximum values of bioluminescence intensity in the presence of control or analyzed sample respectively; $T_{\max }$ is the time when the coupled enzyme system reached the luminescence maximum; $P$ is a time when the bioluminescent signal is absent due to an effect of redox active compounds in a sample.

Fig. (2). Examples of coupling of the enzymatic reactions. (A) The sequence of enzymes in the triple enzyme system: ADH + Red + Luc [32]; (B) interaction of enzymes in the triple enzyme system: trypsin + Red + Luc [33].

Fig. (3). Scheme of ADH (or trypsin) activity measurement using the bioluminescence decay constant: $k_{d}$ background is the decay constant for the coupled enzyme reaction Red + Luc (1); $k_{d \text { control }}$ is the decay constant for the triple enzyme reaction with ADH or trypsin in the presence of control solution (2); $k_{d}$ exp is the decay constant for the triple enzyme reaction with ADH or trypsin with toxic substances: $3 \mathrm{a}$, the pollutant inhibits trypsin or ADH activity; 3b, the pollutant activates trypsin or ADH [16].

Fig. (4). The reagent Enzymolum in a tablet form. Its diameter is 6-7 mm; weight is $1.5 \pm 0.2$ $\mathrm{mg}$ (left - gelatine based reagents, right - starch based reagents). 


\section{Figures}

(A)

(B)
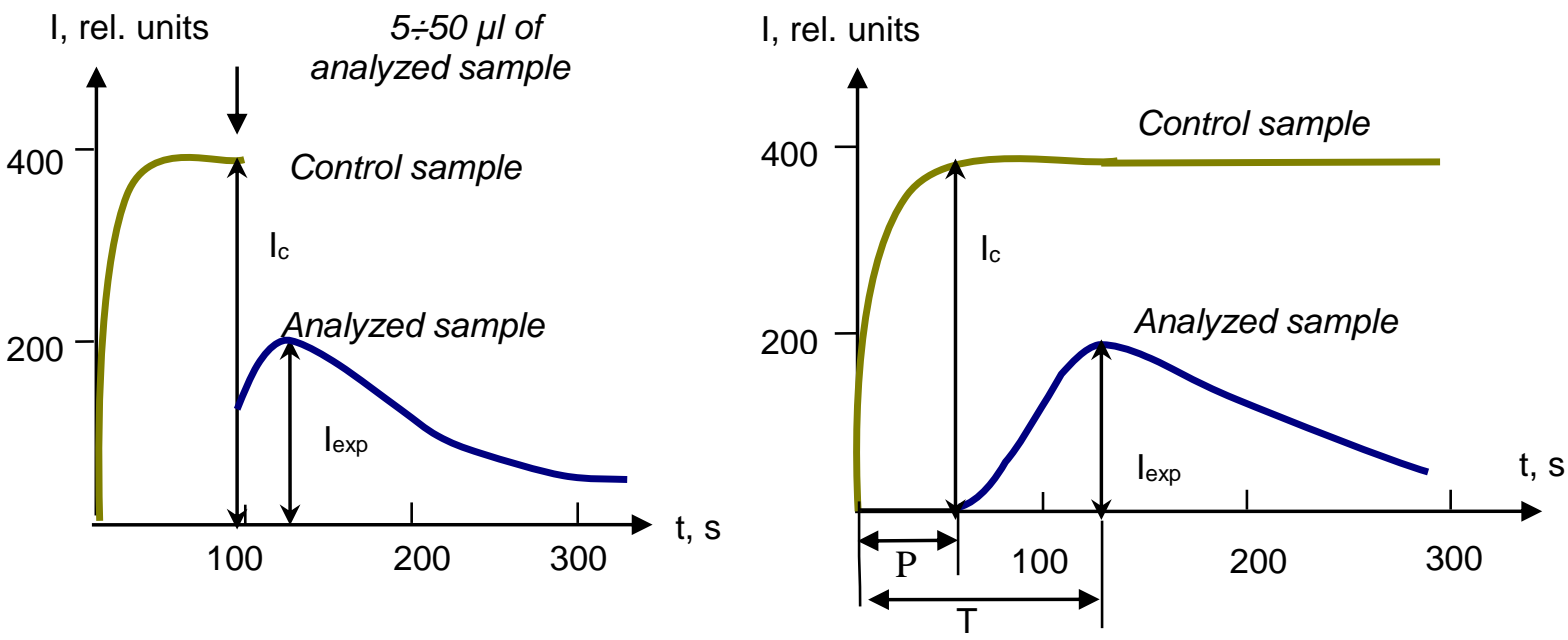

Fig. 1. 
(A)
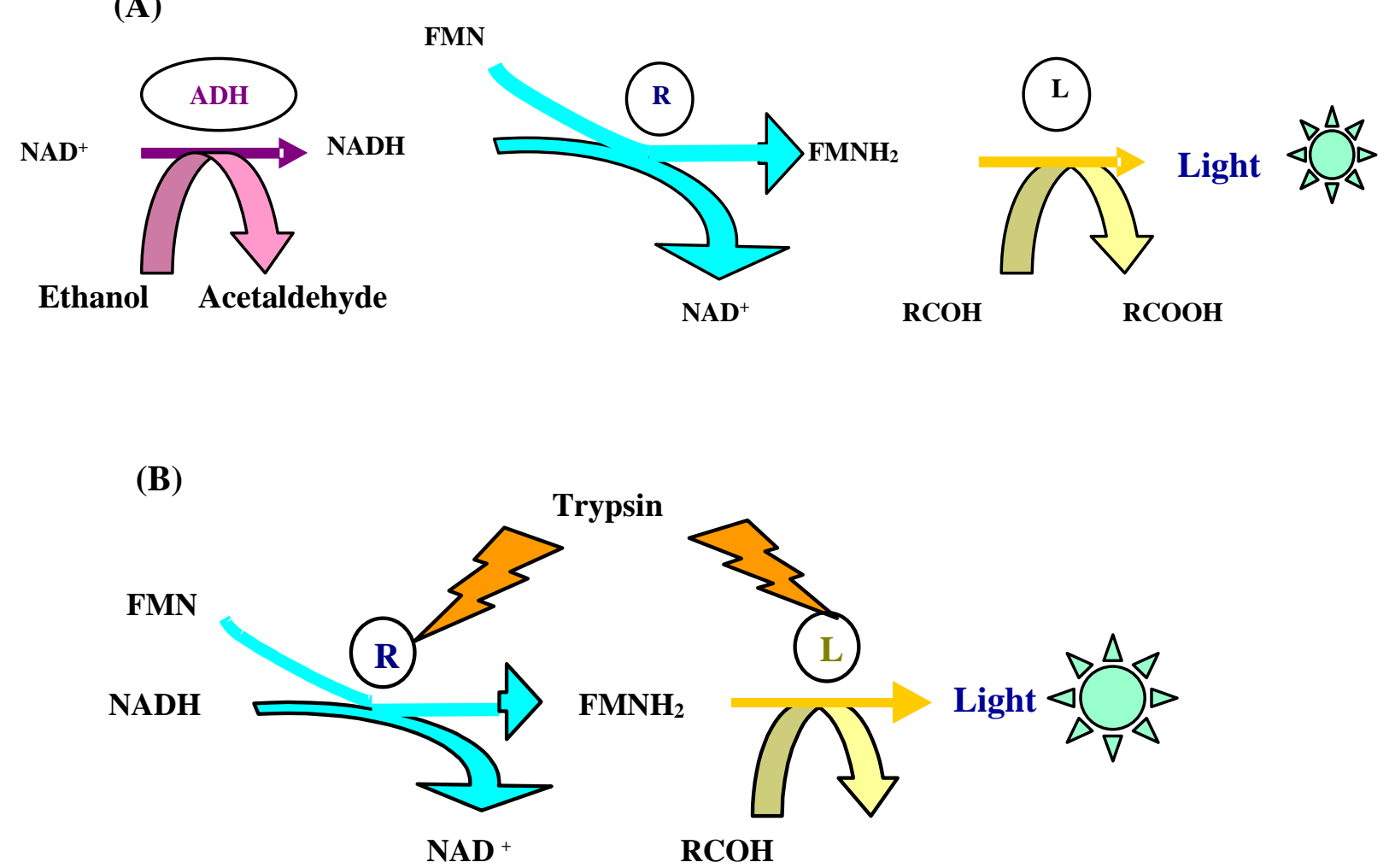

Fig. 2. 


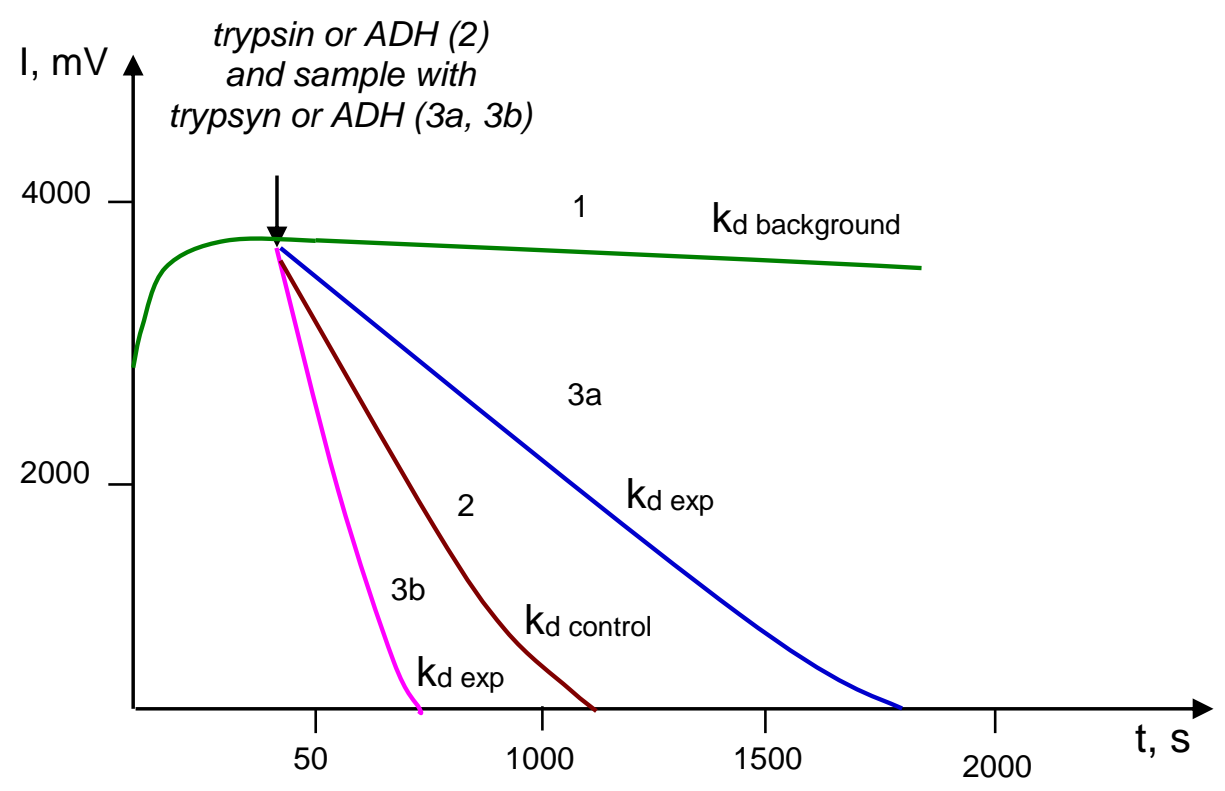

Fig. 3. 


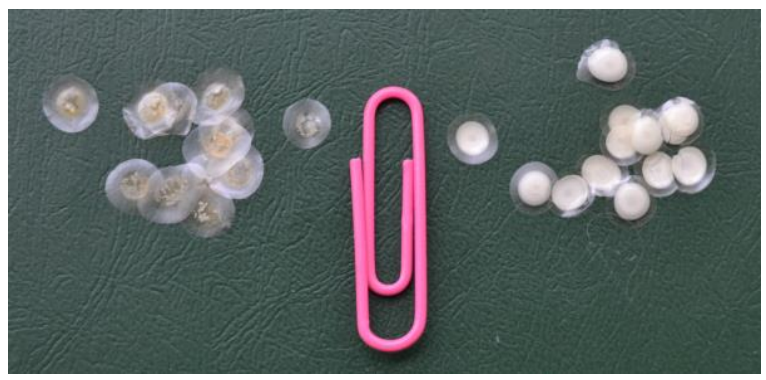

Fig. 4. 